\title{
Isolation and Identification of the Wax Esters from the Cuticular Waxes of Green Tobacco Leaf *
}

\author{
by
}

\author{
R. F. Arrendale, R. F. Severson and O. T. Chortyk
}

Tobacco Safety Research Unit, Agricultural Research Service,

United States Department of Agriculture, Atbens, Georgia, U.S.A.

and

M. G. Stephenson

Nematodes, Weeds and Crops Research Unit, Agricultural Research Service, United States Department of Agriculture, Tifton, Georgia, U.S.A.

\section{SUMMARY}

Recent studies in our laboratory on the cuticular chemicals of green tobacco leaf have revealed the presence of wax esters, composed of fatty acids bound to fatty alcohols. Cuticular components of young green NC 2326 tobacco leaves were removed with methylene chloride, and partitioned between hexane and $80 \% \mathrm{MeOH}-\mathrm{H}_{2} \mathrm{O}$. The hexane-soluble fraction, which contained wax esters, paraffinic hydrocarbons, and fatty alcohols, was separated by silicic acid column chromatography, and the resulting wax ester fraction was further purified by lipophilic gel chromatography. Initial analyses of the wax ester fraction by capillary gas chromatography [GC] and capillary GC/MS, on a short fused silica [FS] SE-54 capillary column, indicated the presence of $\mathrm{C}_{30}-\mathrm{C}_{52}$ wax esters. Application of the cold on-column injection technique and use of immobilized stationary phase, FS SE-54 capillary columns greatly improved the GC separation of the complex wax ester fraction and permitted the identification of individual wax ester isomers. Identification of wax ester isomers by GC/MS relied upon the presence of a molecular ion and ions characteristic of the acid and alcohol moieties. For the acid portion, these ions included the acid $M W+1$ a.m.u. and $M W-17$ a.m.u. ions, while for the alcohol, they were the alcohol $M W-18$ a.m.u. and

\footnotetext{
* Presented, in part, at the 38th 'Tobacco Chemists' Research Conference, Atlanta, Georgia, 1984.

Received: 12th January 1987 - accepted: 25th November 1987.
}

$M W+27$ a.m.u. ions. Saponification of the wax ester fraction and subsequent analyses of the alcohols (as trimethylsilyl ethers) and acids (as methyl esters) revealed extensive iso- and anteiso-methyl branching of the acid moieties. The wax ester isomers with iso- and anteisomethyl-branched acid moieties were separated from each other and from the normal straight-chain isomers by capillary GC and were identified by GC/MS, based upon characteristic ions resulting from the losses of the iso-branched ( $M W-43$ a.m.u.) and anteiso-branched $(M W-57$ a.m.u.) groups from the molecular ion and from the acid moiety. One hundred and seventy individual wax esters were identified.

\section{ZUSAMMENFASSUNG}

Frühere Untersuchungen, die im Laboratorium der Verfasser durchgeführt worden waren, zeigten, $\mathrm{da} \mathrm{B}$ die Oberflāche von grünen Tabakblättern Wachsester enthält, die aus Fettsäuren und Fettalkoholen aufgebaut sind. Die Kutikularwachse jungen grünen Blattgutes der Tabaksorte NC 2326 wurden in der vorliegenden Studie mit Dichlormethan extrahiert und zwischen Hexan und einem $80 \%$ igen Methanol/Wasser-Gemisch verteilt. Die hexanlösliche Fraktion, die Wachsester, paraffinische Kohlenwasserstoffe und Fettalkohole enthält, wurde mittels Säulenchromatographie an Kieselsāure getrennt und die so isolierte Wachsesterfraktion mittels lipophiler Gel-Chromatographie gereinigt. 
Flgure 1.

Isolation of the wax ester fraction: solvent partitioning of the whole-leaf wash from greon NC 2326 tobacco leaves.

SOLVENT PARTITIONING

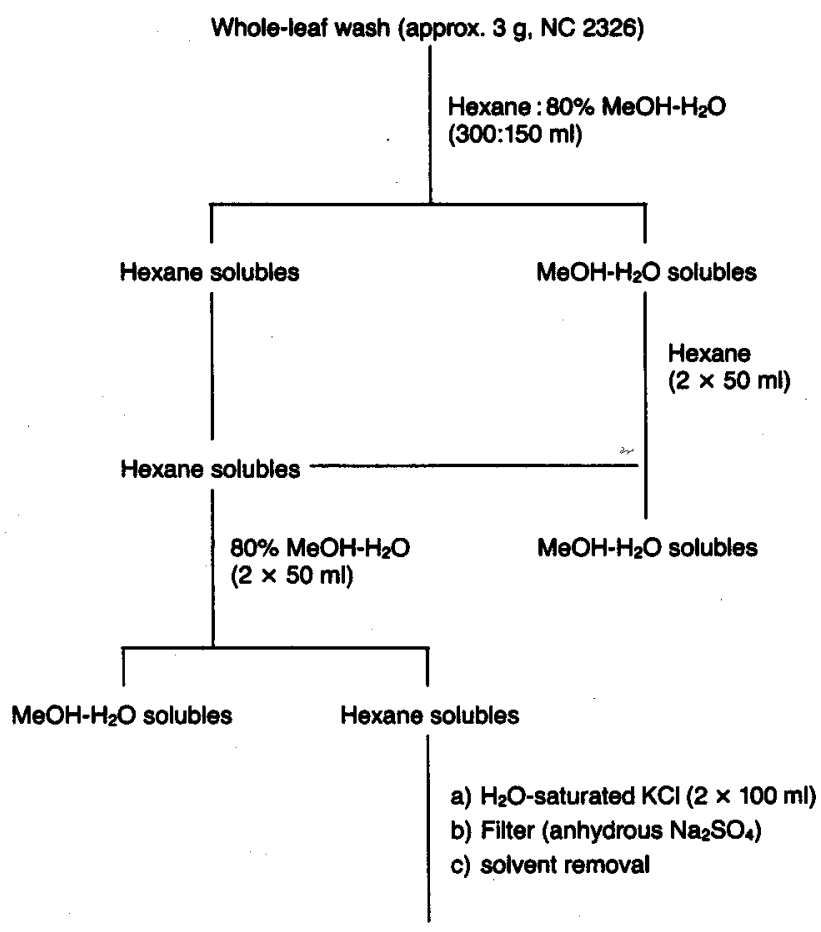

Hydrocarbon, fatty alcohol, wax ester isolate (approx. $1.0 \mathrm{~g}, \mathrm{NC} 2326$ )

Flgure 2.

Isolation of the wax ester fraction: column chromatography of the hydrocarbon, fatty alcohol, wax ester isolate.

COLUMN CHROMATOGRAPHY

Hexane-soluble fraction (approx. $1 \mathrm{~g}, \mathrm{NC} 2326$ )

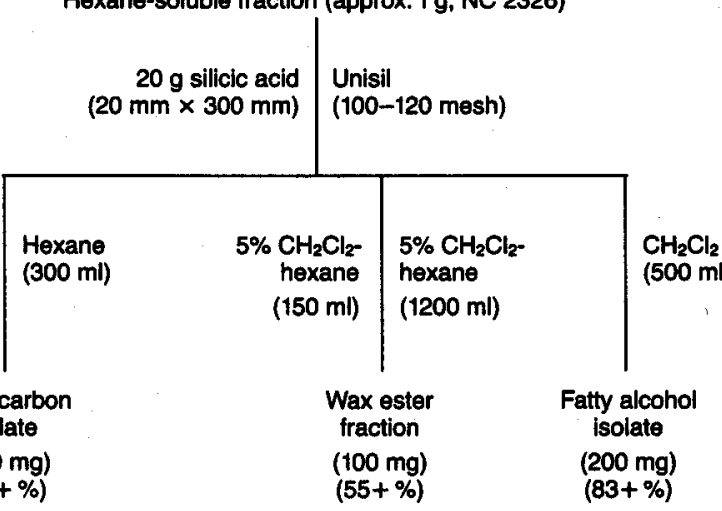

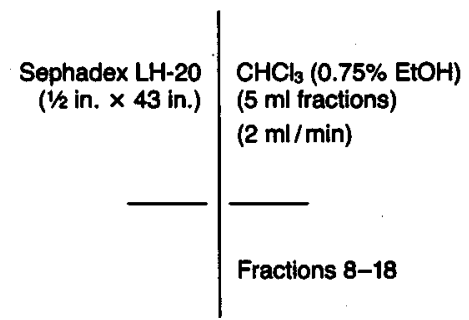

Wax ester isolate

(56 mg) 
Zunächst ließen sich bei der Analyse der Wachsesterfraktion mittels Kapillar-Gaschromatographie [GC] wie auch mittels Kapillar-GC/MS unter Verwendung eines kurzen mit SE-54 beschichteten Quarzglaskapillarrohres [FS] die Wachsester $\mathrm{C}_{30}$ bis $\mathrm{C}_{52}$ nachweisen. Eine erhebliche Verbesserung der gaschromatographischen Trennung der komplexen $W$ achsesterfraktion und die Identifizierung einzelner Wachsesterisomere konnten durch kalte Direkteinspritzung der Proben auf die Säule und die Anwendung einer immobilisierten stationären Phase (Quarzglaskapillarsäule, beschichtet mit SE-54) erreicht werden. Die Identifizierung der Wachsesterisomere durch Gaschromatographie in Verbindung mit Massenspektrometrie basierte auf einem Molekũlion und auf für die Säure- bzw. Alkoholanteile charakteristischen Ionen; für den Sãureanteil sind dies $M W+1$ a.m.u. und $M W-17$ a.m.u. und für den Alkoholanteil $M W-18$ a.m.u. und $M W+27$ a.m.u. Nach Verseifung der Wachsesterfraktion zeigte sich bei der Untersuchung der Alkohole (als Trimethylsilylether) und der Säuren (als Methylester) ein beträchtliches AusmaB an iso- und anteiso-Methylverzweigung der Saureanteile. Die Wachsesterisomere mit iso- und anteiso-methylverzweigten Säuren wurden voneinander und von den normalen geradkettigen Isomeren mit Hilfe von Kapillar-GC getrennt; ihre Identifizierung erfolgte mittels GC/MS auf der Basis charakteristischer Ionen, die sich durch die Abspaltung der iso-verzweigten $(M W-43$ a.m.u.) und anteiso-verzweigten ( $M W-$ 57 a.m.u.) Gruppen von dem Molekülion und dem Sãureanteil ergaben. Es wurden 170 Wachsester identifiziert.

\section{RESUME}

Des examens effectués antérieurement dans le laboratoire de l'auteur avaient révélé à la surface des feuilles de tabac vertes la présence d'esters (cires) dérivant d'acides gras et d'alcools gras. Dans le cadre de la présente étude, les cires cuticulaires de jeunes feuilles vertes de la variété de tabac NC 2326 ont été extraites avec du dichlorométhane et dissoutes en partie dans de l'hexane et en partie dans un mélange d'eau et de méthanol à $80 \%$. La fraction soluble dans l'hexane, qui contenait les esters, des paraffines et des alcools gras, a été séparée dans une colonne chromatographique par adsorption sur gel de silice; les esters ainsi isolés ont été purifiés au moyen d'une chromatographie sur gel lipophile. Au cours de l'analyse de la fraction contenant les esters de cires, on a pu tout d'abord mettre en évidence les esters en $\mathrm{C}_{30}$ à $\mathrm{C}_{32}$ par chromatographie capillaire en phase gazeuse [GC] ainsi que par chromatographie en phase gazeuse associée à la spectrographie de masse [GC/MS], en employant un tube capillaire court en quartz revêtu de SE-54 [FS]. L'injection directe à froid des échantillons sur la colonne et l'utilisation d'une phase stationnaire immobilisée (colonne capillaire en quartz revêtue de SE-54), ont permis d'améliorer considérablement la séparation chromato- graphique de la fraction complexe contenant les esters ainsi que d'identifier différents isomères. L'identification des isomères des esters par chromatographie en phase gazeuse en liaison avec la spectrographie de masse repose sur la présence d'un ion moléculaire et des ions caractéristiques correspondant respectivement aux acides et aux alcools. Pour les acides, il s'agit de $M W$ (poids moléculaire) +1 u.m.a. et $M W-17$ u.m.a.; pour les alcools, de $M W-18$ u.m.a. et $M W+27$ u.m.a. Après saponification de la fraction contenant les esters, l'analyse des alcools (sous forme triméthylsilyléthers) et des acides (sous forme de méthylesters) a montrê une ramification considérable de la partie acide (iso-méthyl et anteiso-méthyl). Les isomères des esters de cires dérivant d'acides ainsi ramifiés ont été séparés les uns des autres ainsi que des isomères à chaine linéaire normale par GC capillaire. Leur identification a été réalisée au moyen de GC/MS sur la base des ions caractéristiques résultant de la coupure des groupes ramifiés iso $(M W-43$ u.m.a.) et anteiso ( $M W-57$ u.m.a.) de I'ion moléculaire et de la partie acide. 170 esters ont ainsi pu être identifiés.

\section{INTRODUCTION}

The presence of long-chain aliphatic esters (wax esters) in extracts of cured tobacco leaf and tobacco smoke was reported by RowLAND and LATIMER (1) and RoDGMAN et al. (2) in 1959. A short time later Rodgman et al. (3) reported the elucidation of the alcohol and acid moieties of this aliphatic long-chain ester fraction from the cigarette smoke of Turkish, Burley, and a cased commercial blend of tobaccos, and also from hexane extracts of Turkish, Burley and flue-cured tobaccos. They found that the alcohol moieties consisted of 16 normal straight-chain alcohols, with chain lengths ranging from $\mathrm{C}_{12}$ to $\mathrm{C}_{27}$ and with 1-docosanol $\left(\mathrm{C}_{22}-\mathrm{OH}\right)$ as the major isomer. The acids consisted of $\mathrm{C}_{14}$ to $\mathrm{C}_{28}$ normal straight-chain acids and oleic, linolenic and several unknown acids, with $C_{16}$ ( $n$-hexadecanoic) being the major acid.

In recent years, Sevrrson et al, have extensively investigated the cuticular chemicals from green tobacco leaf of different tobacco types (4-6). The major cuticular components from green tobacco leaf were: (a) $\mathrm{C}_{25}-$ $\mathrm{C}_{36}$ normal and branched-chain aliphatic hydrocarbons, (b) diterpenes and (c) sucrose esters. During these studies, a series of high molecular weight wax esters were found to occur as minor components in the cuticular waxes of green tobacco leaves $(4,6)$.

Due to their high molecular weights, relatively low levels, poor detector responses, and complexity, the wax esters could not be analyzed under the same GC conditions used for analyses of the major cuticular components. However, applications of recent advances in analytical capillary GC methodology, such as cold on-column injection (7) and use of immobilized stationary phase fused silica [FS] SE-54 capillary columns (8) 
Figure 3.

Inltial gas chromatogram of the wax ester fraction from green NC 2326 tobacco leaf. The numbers in brackets indicate the acid and alcohol residues, respectively, of the predominate wax esters. Conditions: FS SE-54 column, $3.5 \mathrm{~m} \times 0.3 \mathrm{~mm}$ inside diameter; temperature program, 200-300 ${ }^{\circ} \mathrm{C}$ at $2 \% / \mathrm{min}$; column flow, $100 \mathrm{~cm} / \mathrm{s}_{2}$; split injection; flame ionization detector (FID).

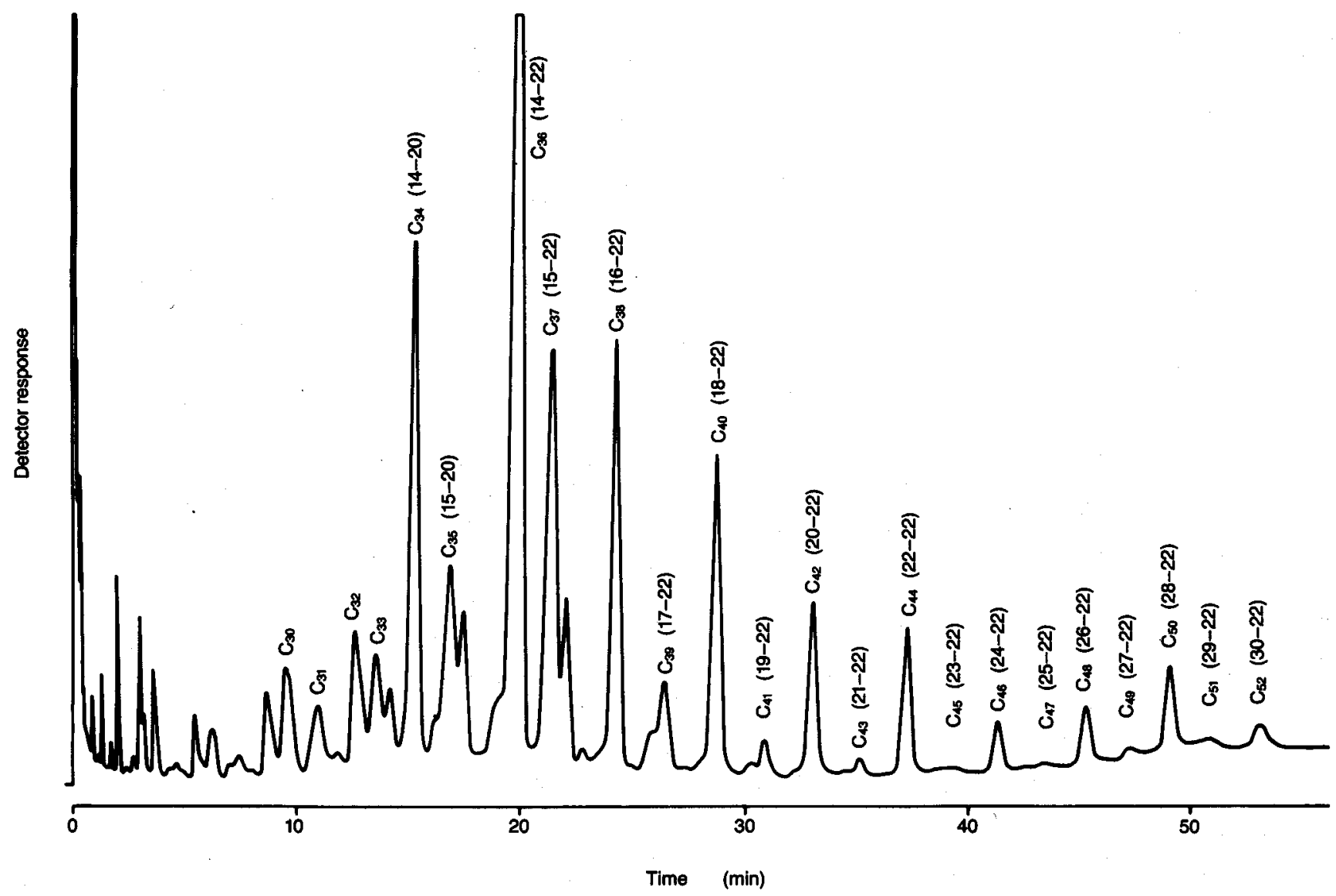


greatly improved the analysis of these compounds. The isolation of the wax esters and the separation and identification of individual isomers by capillary GC / MS are the subjects of this report.

The relationship of the cuticular wax esters to hostplant resistance, growth regulation and tobacco quality is not well understood. However, it has been demonstrated that Tobacco Introduction [TI] 1406 (Virgin A mutant), whose cuticular chemicals contain normal to high levels of wax esters and fatty alcohol but only trace levels of duvanes, sucrose esters and labdanes, shows resistance to potato virus $\mathrm{Y}[\mathrm{PVY}](9,10)$. Developed lines with PVY resistance have compositions of surface chemicals similar to that of the parent TI 1406 (6).

\section{EXPERIMENTAL}

\section{Materials}

The tobacco used in this work was grown under fluecured cultural conditions at the University of Georgia Coastal Plain Experiment Station, Tifton, Ga. Solvents (hexane, methanol, methylene chloride, benzene, and isooctane) were distilled-in-glass grade (Burdick and Jackson, Richmond, Calif.) * and were used as received. Silicic acid (unrsru, 100-200 mesh, Clarkson Chemical Company, Inc., Williamsport, Pa.) was heated overnight in an oven at $150^{\circ} \mathrm{C}$. Sephadex LH-20 (Pharmacia Fine Chemicals, Piscataway, N.J.) and $\mathrm{BF}_{3}$-methanol (Applied Science Laboratories, State College, $\mathrm{Pa}$.) were used as received. The FS capillary columns used in this work were prepared in our laboratory (8).

\section{Synthesis of Wax Ester Standards}

Standard wax esters $\left(\mathrm{C}_{28}-\mathrm{C}_{42}\right)$ were prepared by esterification of the selected carboxylic acid with the desired alcohol. Approximately 3.5 millimoles of the alcohol and 5 millimoles of the carboxylic acid were dissolved in $15 \mathrm{ml}$ of toluene and transferred to a $25 \mathrm{ml}$ round bottom flask. Approximately 4 drops of concd. $\mathrm{H}_{2} \mathrm{SO}_{4}$ were added and the round bottom flask was connected to a Dean-Stark receiving trap (filled with toluene) and a condenser. Boiling beads were added and the mixture was heated for $4 \mathrm{~h}$, during which time water was observed to form in the Dean-Stark trap and the condenser. The residue was dissolved in $300 \mathrm{ml}$ of ether and transferred to a $500 \mathrm{ml}$ separatory funnel where it was extracted $(2 \times 200 \mathrm{ml})$ with saturated $\mathrm{NaCl}$ solution. The organic phase was dried over $\mathrm{Na}_{2} \mathrm{SO}_{4}$, evaporated to dryness on a rotary evaporator, and transferred with hexane to a $100 \mathrm{~g}$ basic alumina column (prepared in hexane). The wax ester was eluted from the column with $1500 \mathrm{ml}$ of diethyl ether in two

\footnotetext{
t Names of products are included for the benefit of the reader and do not
} imply endorsement or preferential treatunent by U.S.D.A. fractions: $1000 \mathrm{ml}$ and $500 \mathrm{ml}$, respectively. These fractions were evaporated to dryness on a rotary evaporator and the wax esters were recrystallized from hot ether or from pentane. Their melting points were determined and their purity and relative retention times were determined by capillary GC.

\section{Isolation of the Wax Ester Fraction}

Solvent Partitioning: The cuticular components of green NC 2326 tobacco were removed by dipping the young leaves into methylene chloride, as described previously (4). After removal of the solvent on a rotary evaporator, approximately $3 \mathrm{~g}$ of the whole leaf wash, representing the cuticular components from 50 to 100 plants, were partitioned between hexane and $80 \%$ methanol- $\mathrm{H}_{2} \mathrm{O}$ (Fig. 1) to yield approximately $1.0 \mathrm{~g}$ of a hexane-soluble fraction containing hydrocarbons, fatty alcohols and wax esters.

Column Chromatography: Approximately $1 \mathrm{~g}$ of the hydrocarbon, fatty alcohol, wax ester isolate was subjected to silicic acid column chromatography (Fig. 2). The wax ester fraction (about $100 \mathrm{mg}$ ) was eluted with $5 \%$ methylene chloride in hexane. The wax esters represented about half of the material by weight. This fraction was further purified by gel chromatography on Sephadex LH-20 in chloroform to yield about $56 \mathrm{mg}$ of the wax ester isolate (Fig. 2).

Saponification of the Wax Ester lsolate: A portion of the wax ester isolate $(10-20 \mathrm{mg})$ was heated with $5 \mathrm{ml}$ of $2 \mathrm{~N} \mathrm{KOH}$, at $90^{\circ} \mathrm{C}$ for $2 \mathrm{~h}$. After cooling, $10 \mathrm{ml}$ of a 1:1 mixture of benzene : $85 \%$ ethanol were added. The solution was then extracted with hexane $(3 \times 10 \mathrm{ml})$ to yield a hexane-soluble fraction, containing the fatty alcohols, and an ethanol:water soluble fraction, containing the potassium salts of the fatty acids. The fatty alcohols were then converted to their trimethylsilyl [TMS] ethers with 1:1 BSTFA/DMF* and were analyzed by capillary GC and capillary GC / MS. The free fatty acids were extracted into methylene chloride, after adjusting the ethanol:water solution to $\mathrm{pH} 2$ with cold concentrated $\mathrm{HCl}$, adding $5-10 \mathrm{ml}$ of saturated $\mathrm{KCl}$, and extracting with methylene chloride $(3 \times 10 \mathrm{ml})$. The free acids were converted to fatty acid methyl esters [FAME] by heating in $\mathrm{BF}_{3}$ :methanol, followed by extraction of the FAME into hexane. The FAME were also analyzed by capillary $\mathrm{GC}$ and $\mathrm{GC}$ / MS.

Capillary Gas Chromatography: The initial separation of the wax ester isolate (Fig. 3) was made on a short ( $3.5 \mathrm{~m} \times 0.25 \mathrm{~mm}$ inside diameter) FS SE-54 capillary column in the split injection mode. Mass spectral data from the $\mathrm{GC} / \mathrm{MS}$ analysis of the isolate indicated the

\footnotetext{
- $N, O$-Bis(trimethylsily])trifluoroaceramide/dimethyltormamide.
} 
Flgure 4.

Chromatogram of the concentrated portion of the wax ester fraction from NC 2326 tobacco. Conditions: FS SE-54 column, $28 \mathrm{~m} \times 0.3 \mathrm{~mm}$ inside diameter; temperature program, $90-210^{\circ} \mathrm{C}$ at $20^{\circ} / \mathrm{min}$, and $210-330{ }^{\circ} \mathrm{C}$ at $3^{\circ} / \mathrm{min}$; column flow, $35 \mathrm{~cm} / \mathrm{s} \mathrm{H}_{2}$; cold on-column injection; injection volume, $1 \mu$ isooctane; FID.

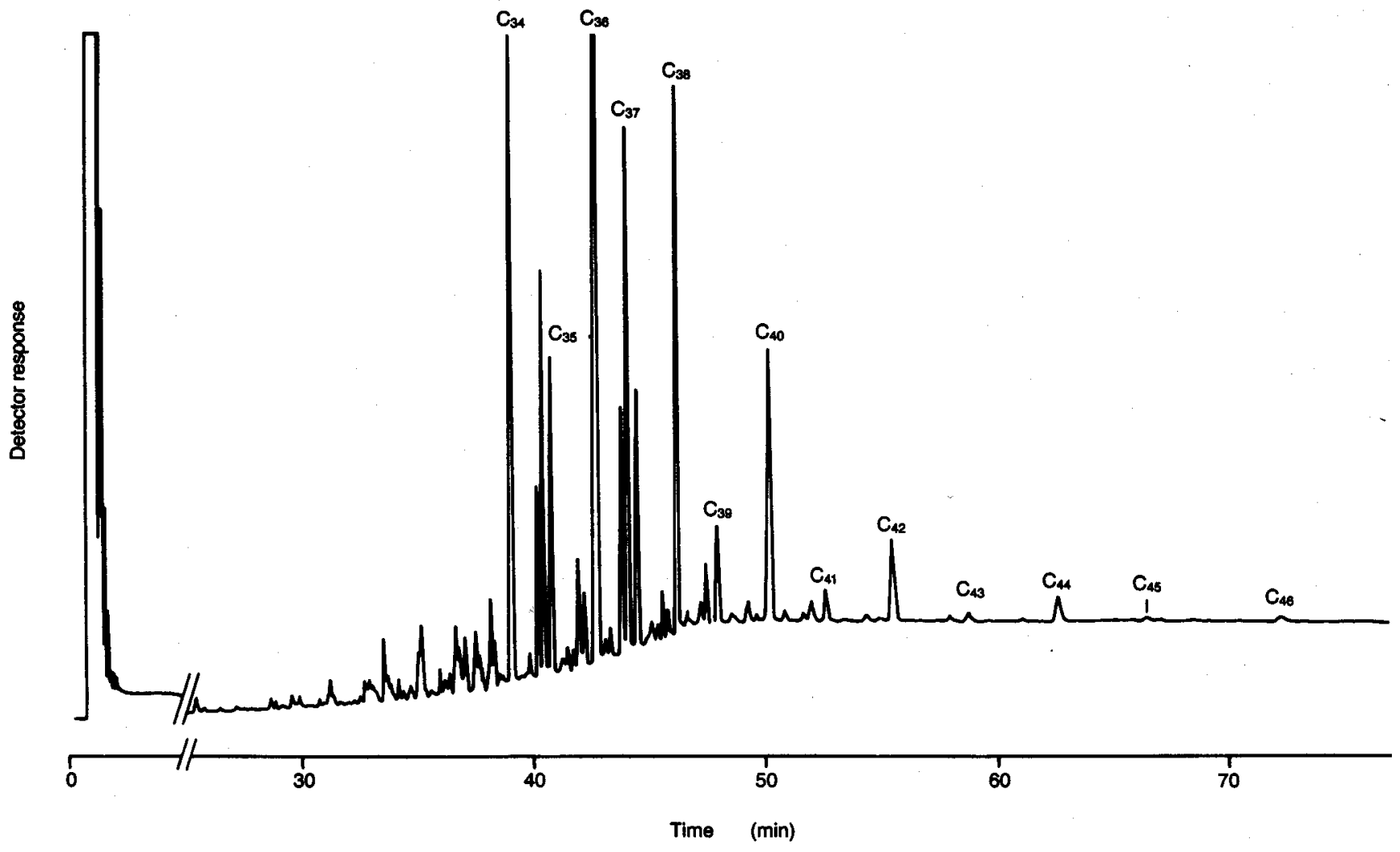

Flgure 5. ,

Chromatogram of the low-level high molecular weight wax esters from NC 2326 tobacco. Conditions: FS SE-54 column, $28 \mathrm{~m} \times 0.3 \mathrm{~mm}$ inside diameter; temperature program, $90^{\circ} \mathrm{C}$ for $1 \mathrm{~min}$, $90-330^{\circ} \mathrm{C}$ at $10^{\circ} / \mathrm{min}$; column flow, $45 \mathrm{~cm} / \mathrm{s} \mathrm{H}_{2}$; cold on-column injection; injection volume, $1 \mu$ isooctane; FID.

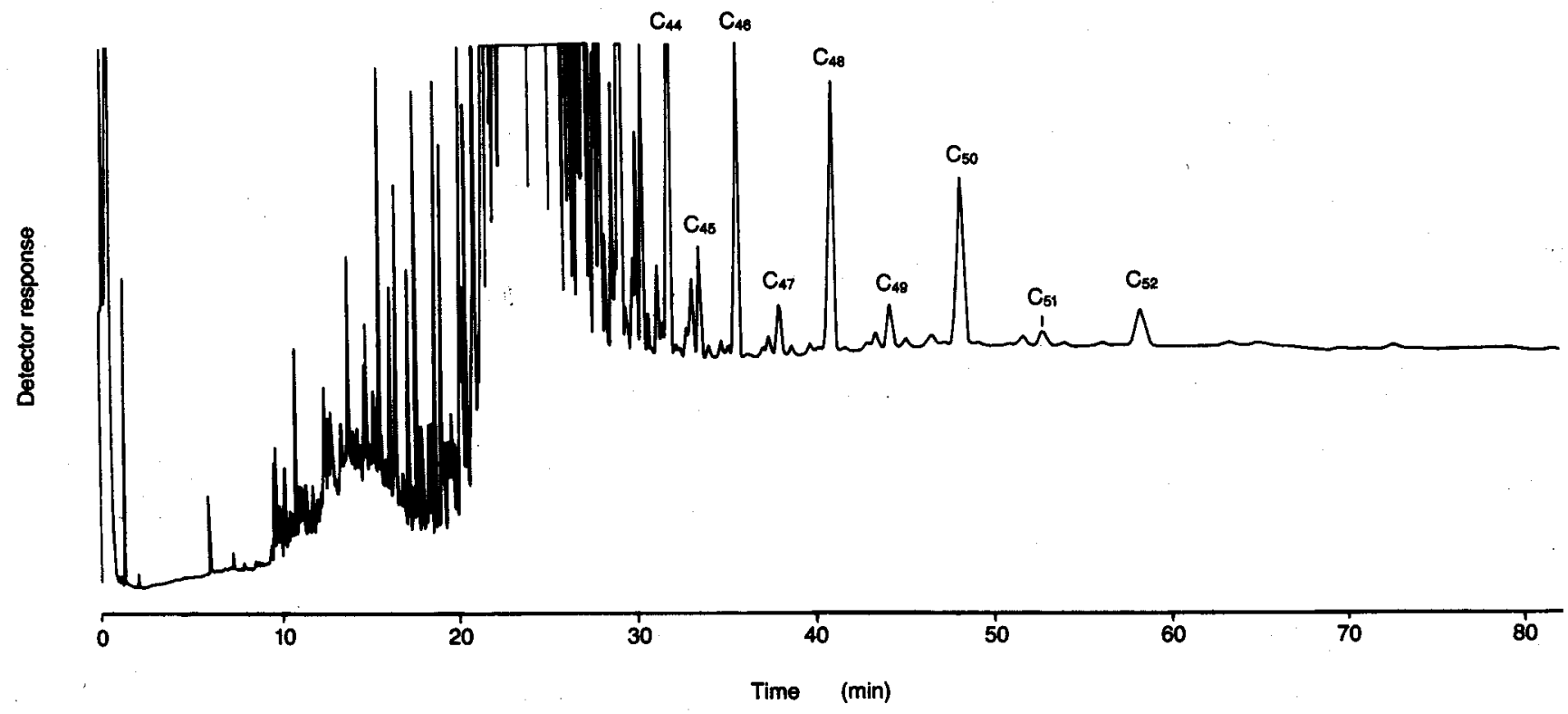


presence of $C_{30}-C_{52}$ wax esters and also showed that the wax ester isolate was composed of many different isomers. The separation and the identification of the individual wax esters were hampered by their relatively low volatilities. To achieve better GC separation, cold on-column injection capillary GC (7) with an immobilized stationary phase FS SE-54 capillary column was used (8). The complexity of the fraction and the relatively low concentration of the $\mathrm{C}_{44}-\mathrm{C}_{32}$ wax esters further required the division of the analysis into two parts. The first GC separation required conditions for the analysis of the concentrated portion of the wax esters $\left(C_{30}-C_{44}\right)$ (Fig. 4), while the second separation required conditions for the analysis of the less abundant higher molecular weight isomers $\left(\mathrm{C}_{44}-\mathrm{C}_{52}\right)$ (Figure 5).

Capillary Gas Chromatography / Mass Spectrometry: Capillary GC / MS analyses of the wax ester isolate and of the fatty alcohols (TMS) and the fatty acids (FAME) from the hydrolysis of the wax ester isolate were performed on a Hewlett-Packard 5985B GC/MS system. The FS capillary columns were connected to the MS source with an open-split interface (11). The MS conditions for these analyses were as follows: GC/MS interface zone temperature, $300^{\circ} \mathrm{C}$; ion source temperature, $200^{\circ} \mathrm{C}$; electron energy, $70 \mathrm{eV}$; scan range, 40-650 a.m.u. for concentrated wax ester analyses (Fig. 4), 200-800 a.m.u. for low-level wax ester analyses (Figure 5); scan rate, 266.7 a.m.u./s for concentrated wax ester analyses (Fig. 4), 400 a.m.u./s for low-level wax ester analyses (Fig. 5); electron multiplier voltage, $2200 \mathrm{~V}$ for concentrated wax ester analysis (Fig. 4), $2800 \mathrm{~V}$ for low-level wax ester analyses (Fig. 5).

\section{RESULTS AND DISCUSSION}

Chromatograms of the capillary GC separations of the fatty acids (FAME) and fatty alcohols (TMS) from the saponification of the wax ester isolate are shown in Figures 6 and 7, respectively. The capillary GC/MS data for the fatty acids (FAME) showed the presence of $\mathrm{C}_{12}-\mathrm{C}_{32}$ acids with extensive iso- and anteiso-methyl branching (about $25 \%$ ), especially in the odd carbon number isomers. The major fatty acid isomer from the saponification of the wax ester isolate was n-tetradecanoic acid. RoDGMan et al. (3) reported that the major acid found in their ester fraction from cured tobacco leaf and tobacco smoke was $n$-hexadecanoic $\left(C_{16}\right)$. This apparent difference in the predominant acid found in their ester fraction $\left(\mathrm{C}_{16}\right)$ and that found in our cuticular wax ester fraction $\left(C_{14}\right)$ can be easily explained by the predominance of the $C_{16}$ and $C_{18}$ unsaturated isomers in the esters associated with the interior of the tobacco leaf. Capillary GC/MS analyses of the fatty alcohols revealed a predominantly straight-chain series $\left(\mathrm{C}_{16}-\right.$ $\mathrm{C}_{34}$ ) with 1-docosanol being the most abundant aliphatic alcohol.
In a previous work (6), the relative distributions of the free alcohols from the cuticular chemicals of NC 2326 tobacco were determined and are compared to those of the bound alcohols and acids in the wax esters ( $\mathrm{T}_{2}$ ble 1). It appears that the relative distributions of the free and bound fatty alcohols are identical for all practical purposes. These data, combined with the lack of free acids on the leaf surface, indicate that the fatty alcohols are produced in abundance and exist on the leaf in both the bound ( $\operatorname{wax}$ esters) and free states, while the fatty acids exist only in the bound (wax esters) form.

Table 1.

Relative distribution of cutlcular free alcohols and bound alcohols and acids from the wax ester traction of NC 2326 tobacco.

\begin{tabular}{|c|c|c|c|}
\hline \multirow{3}{*}{ Isomer ${ }^{* * *}$} & \multicolumn{3}{|c|}{ Relative distribution * } \\
\hline & \multirow{2}{*}{ Alcohols } & \multicolumn{2}{|c|}{ Wax ester } \\
\hline & & alcohols **,++ & acids $^{+,++}$ \\
\hline$n-12$ & $-^{+++}$ & - & 0.3 \\
\hline$a+n-13$ & - & - & 0.3 \\
\hline$n-14$ & - & - & 100.0 \\
\hline$i-15$ & - & - & 13.5 \\
\hline$a-15$ & - & - & 29.5 \\
\hline$n-15$ & - & - & 9.2 \\
\hline$n-16$ & - & 0.1 & 33.5 \\
\hline$i+a-17$ & - & - & 3.0 \\
\hline$n-17$ & - & - & 1.9 \\
\hline$n-18$ & 1.3 & 1.5 & 26.2 \\
\hline$i+a-19$ & - & - & 1.3 \\
\hline$n-19$ & 0.5 & 0.3 & 0.8 \\
\hline$n-20$ & 33.7 & 36.4 & 15.0 \\
\hline$i+a-21$ & 2.1 & 2.2 & 0.4 \\
\hline$n-21$ & 6.7 & 7.7 & 0.4 \\
\hline$n-22$ & 100.0 & 100.0 & 10.2 \\
\hline$i+a-23$ & 3.1 & 3.0 & 0.3 \\
\hline$n-23$ & 1.7 & 2.0 & 0.3 \\
\hline$n-24$ & 5.4 & 6.2 & 2.2 \\
\hline $\mathrm{i}+n-25$ & 0.5 & 0.5 & 0.2 \\
\hline$n-25$ & 1.4 & 1.3 & 0.2 \\
\hline$n-26$ & 3.2 & 2.9 & 4.3 \\
\hline $1+a-27$ & - & - & 0.1 \\
\hline$n-27$ & 2.2 & 1.5 & 0.3 \\
\hline$n-28$ & 2.5 & 3.0 & 13.2 \\
\hline$i+a-29$ & - & - & 0.1 \\
\hline$n-29$ & - & - & 0.2 \\
\hline$n-30$ & 1.3 & 4.0 & 1.8 \\
\hline
\end{tabular}

* Relative to the major alcohol (1-docosanol) or the major acid (tetradecanoic).

** Analyzed as trimethylsilyl derivatives on SE-54 column.

"** i: iso-branched, a: anteiso-branched, $n$ : normal straight chain.

+ Analyzed as methyl esters on Silar $10 \mathrm{C}$ column.

++ After hydrolysis of the wax ester isolate.

+++ Absent or below detection limits. 
Figure 6.

Gas chromatogram of the fatty acid methyl esters [FAME] from the hydrolysis of the wax esters of NC 2326 tobacco and a FAME standard mixture. Conditions: FS Carbowax 20M-3 NPA column, $30 \mathrm{~m} \times 0.3 \mathrm{~mm}$ inside dlameter; temperature program, $90{ }^{\circ} \mathrm{C}$ for $1 \mathrm{~min}, 90-230^{\circ} \mathrm{C}$ at $4^{\circ} / \mathrm{min}$; column flow, $25 \mathrm{~cm} / \mathrm{s} \mathrm{He}$; cold on-column injection; injection volume, $1 \mu$ of isooctane; FID.

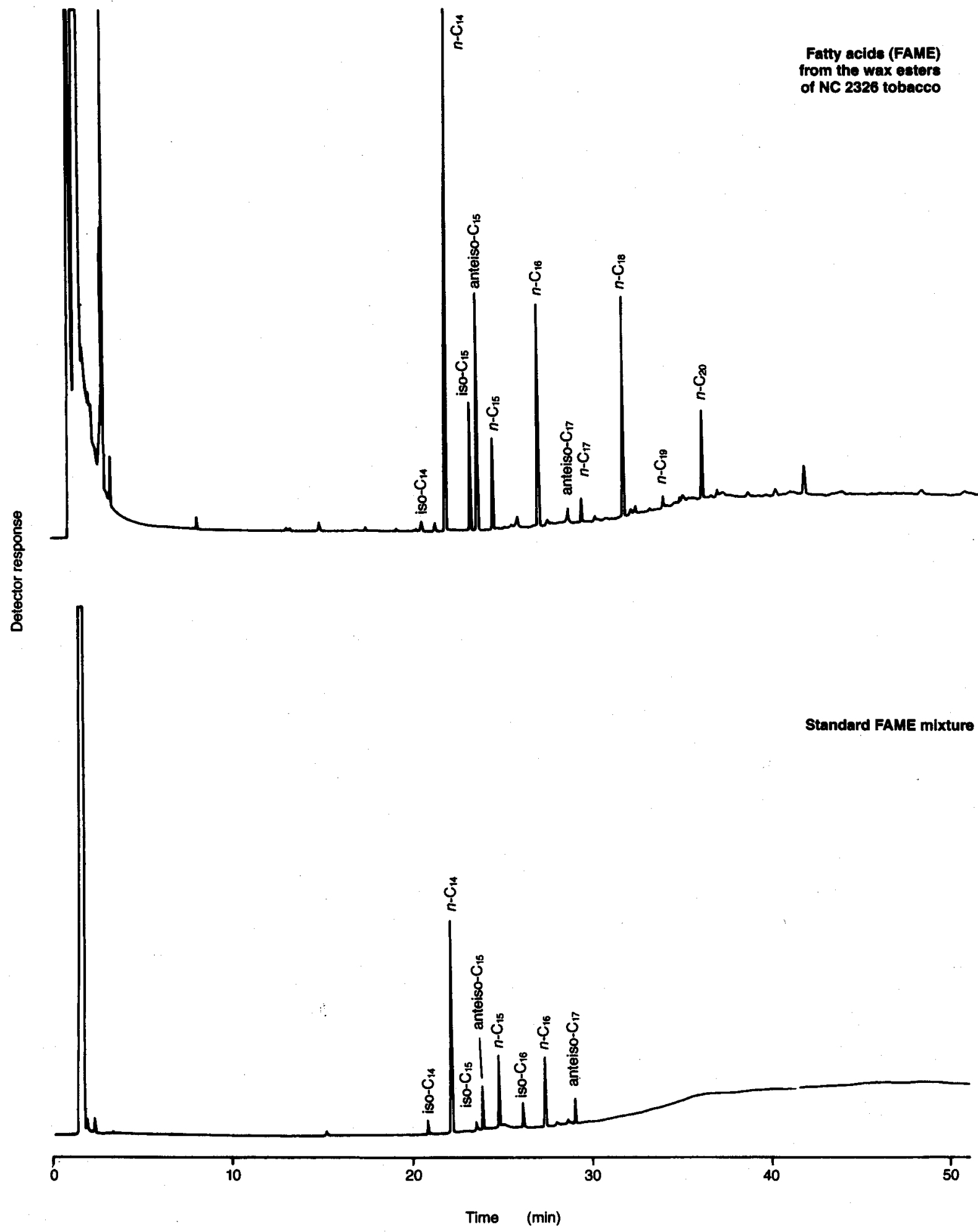


Diagnostic ions for the wax ester isomers generally result from cleavages at or near the ester linkage and are related to the alcohol and acid moieties. The more important fragmentations resulting from electron bombardment of a wax ester molecule are shown in Fig. 8 (12). Two mechanisms (Figures 8A and 8B) are given for ions resulting from the elimination of a molecule of acid to give rise to ionic species of the same mass. The first mechanism (Fig. 8A) is equivalent to the elimination of a neutral molecule of water from a normal straight-chain alcohol in which the carbonyl group is not directly involved in the fragmentation sequence. In the second mechanism (Fig. 8B), the carbonyl is involved in the fragmentation. The extent to which each of these mechanisms contributes to the formation of the ionic species is unknown. However, the resulting ion is diagnostically useful and is equal to the molecular weight of the alcohol -18 a.m.u. This ion is low in intensity but is usually present in the mass spectra of wax esters.

Possible ions resulting from cleavage next to the carbonyl group are shown in Figures $8 \mathrm{C}$ and $8 \mathrm{D}$. Cleavage on the acid side of the carbonyl (Fig. 8C) could result in an ion composed of the alkyl portion of the acid moiety. This ion is prominent in short-chain esters; however, it is not an intense ion for long-chain esters and is relatively unimportant in the spectra of the wax esters. The other ion composed of the alcohol moiety plus the carbonyl does occur in the spectra of wax esters, although it is also low in intensity. This ion is equivalent to the mass of the alcohol +27 a.m.u. Ions resulting from cleavage on the alcohol side of the carbonyl are shown in Fig. 8D. The first of these two ions and the only diagnostically important one is equivalent

\section{Figure 7.}

Gas chromatogram of fatty alcohols (TMS) from the hydroly$8 / 8$ of the wax eaters of NC 2326 tobacco. Conditions: FS SE54 column; temperature program, $180-280^{\circ} \mathrm{C}$ at $4^{\circ} / \mathrm{min}$; column flow, $30 \mathrm{~cm} / \mathrm{s} \mathrm{He}$; split injection; FID.

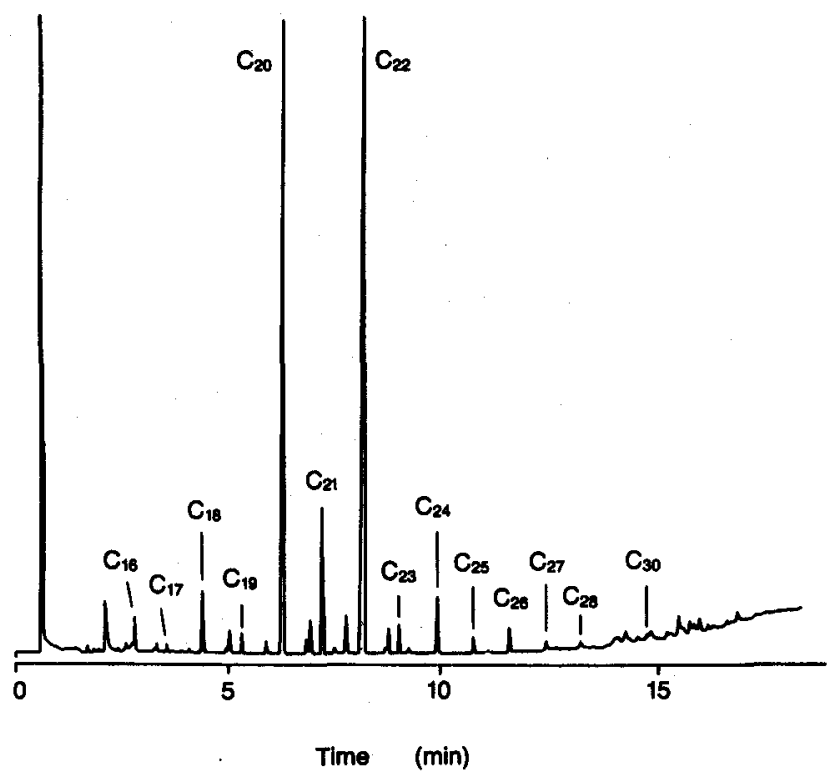

to the acid mass minus a hydroxyl group (acid - 17). For all practical purposes, the remaining alcohol fragment does not appear in spectra of the wax esters.

An ion can also result from the transfer of two hydrogens to the acid moiety and subsequent elimination of the remainder of the alkyl portions of the alcohol moiety to give rise to a protonated acid ion (Fig. 8E). This ionic species, occurring at a mass equal to the acid +1 a.m.u., is very intense and is often the base peak in mass spectra of wax esters. The acid +1 ion and the molecular ion are the two most important diagnostic ionic species in the mass spectra of wax esters, as the mass of the wax ester and the acid moiety are obtained directly and the mass of the alcohol moiety is then easily deduced. In summary, the diagnostic ions for wax esters are: molecular ion; acid +1 a.m.u.; acid 17 a.m.u.; alcohol -18 a.m.u.; and the alcohol +27

a.m.u.

Figure 8.

Dlagnostic ions for mass spectral characterization of wax esters.

Ions resulting from the elimination of a molecule of ecid

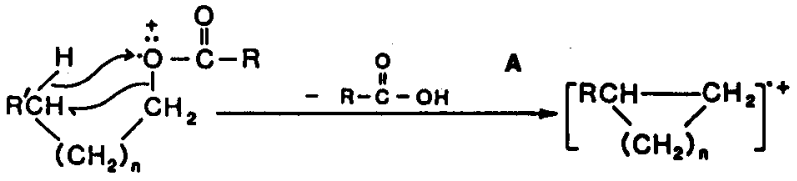

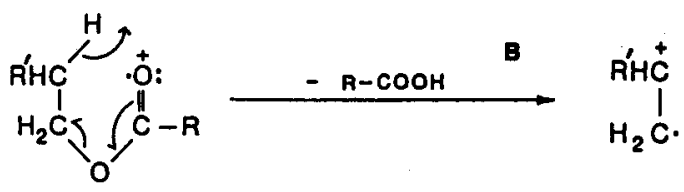

lons reaulting from cleavage next to $\mathrm{C}=\mathrm{O}$
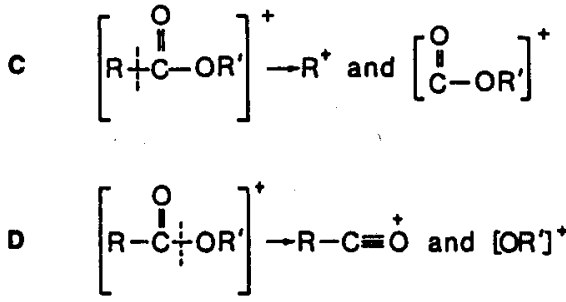

lons resulting from the ellmination of the alkyl moiety

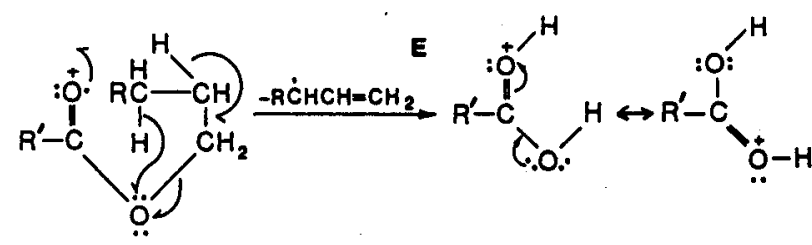


Figure 9.

Mass spectrum of the $\mathrm{C}_{34}$ wax ester (n-elcosyl n-tetradecanoate).
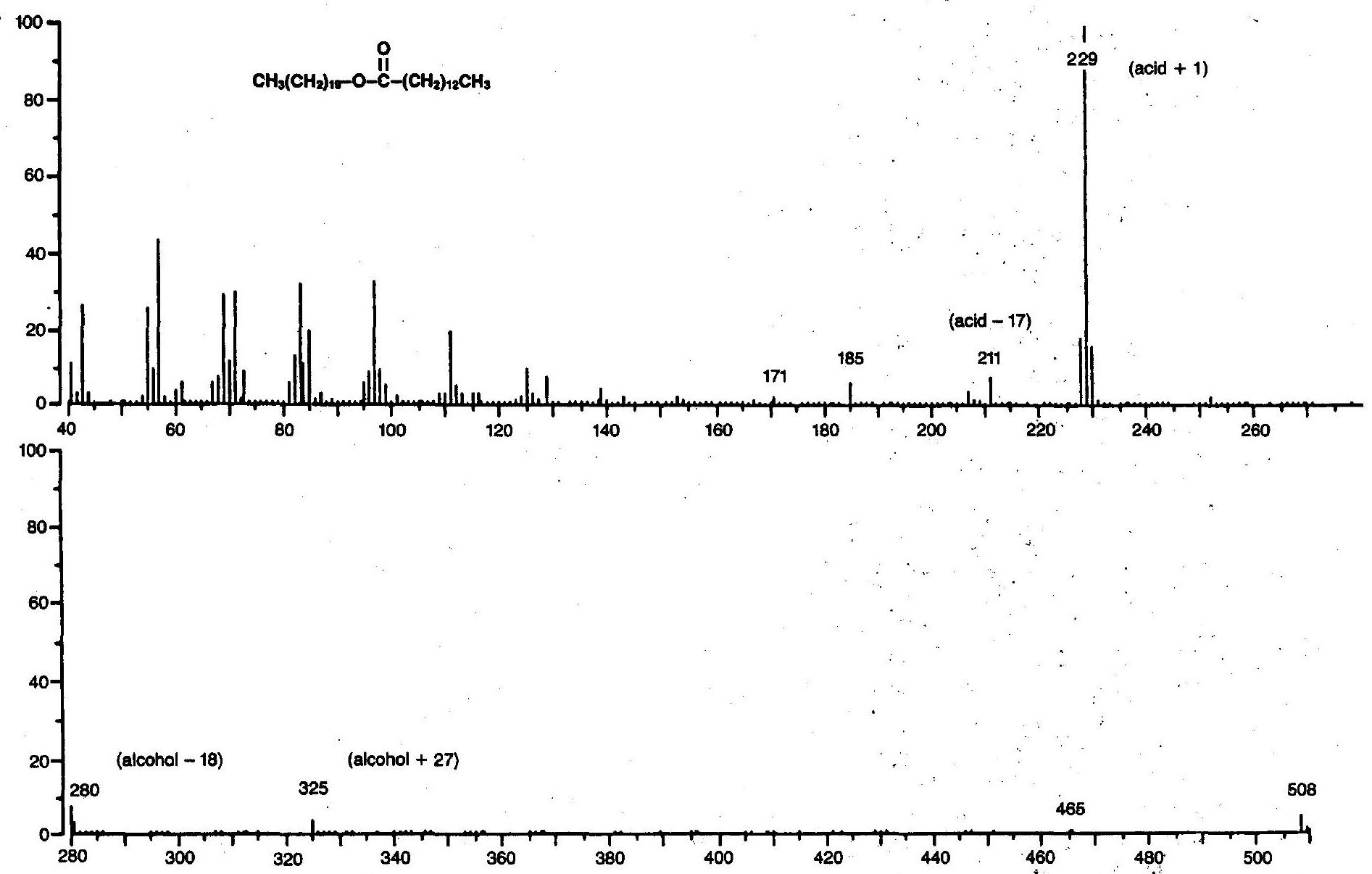
Figure 10.

Mase spectra of lao-branched (A: n-eicosyl i-péntadecanoate) and anteiso-branched (B: n-eicosyl a-pentadecanoate) $C_{36}$ wax esters.
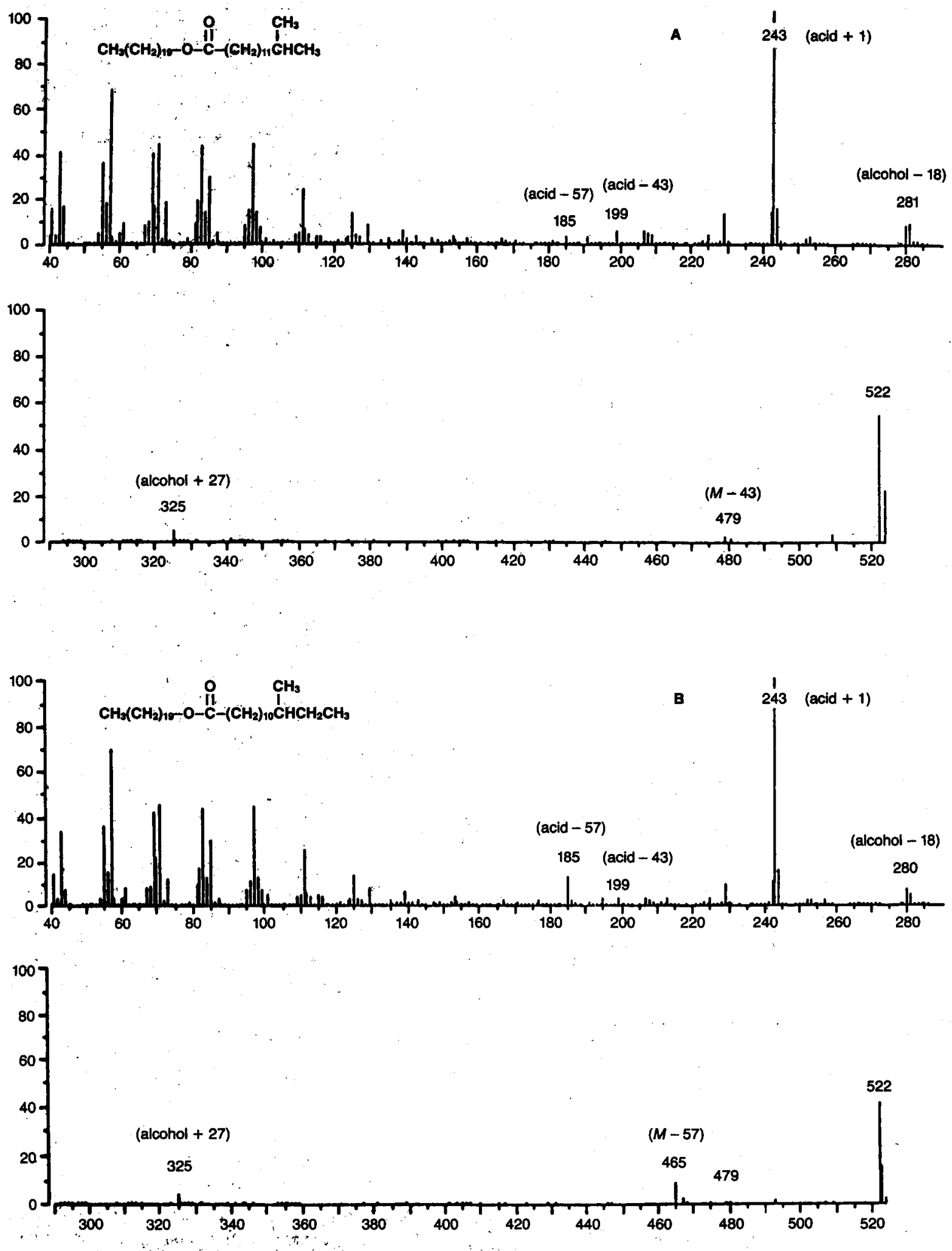

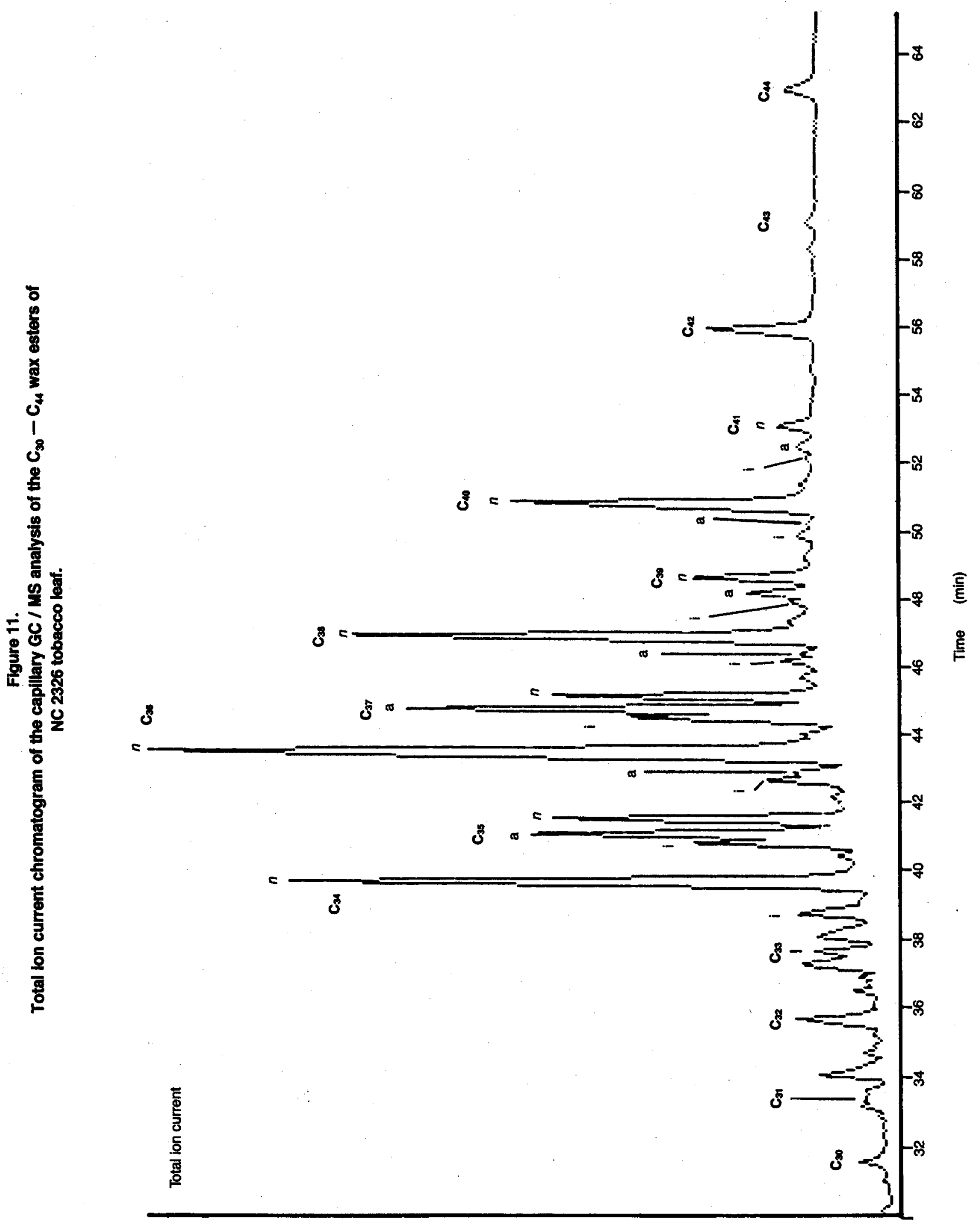


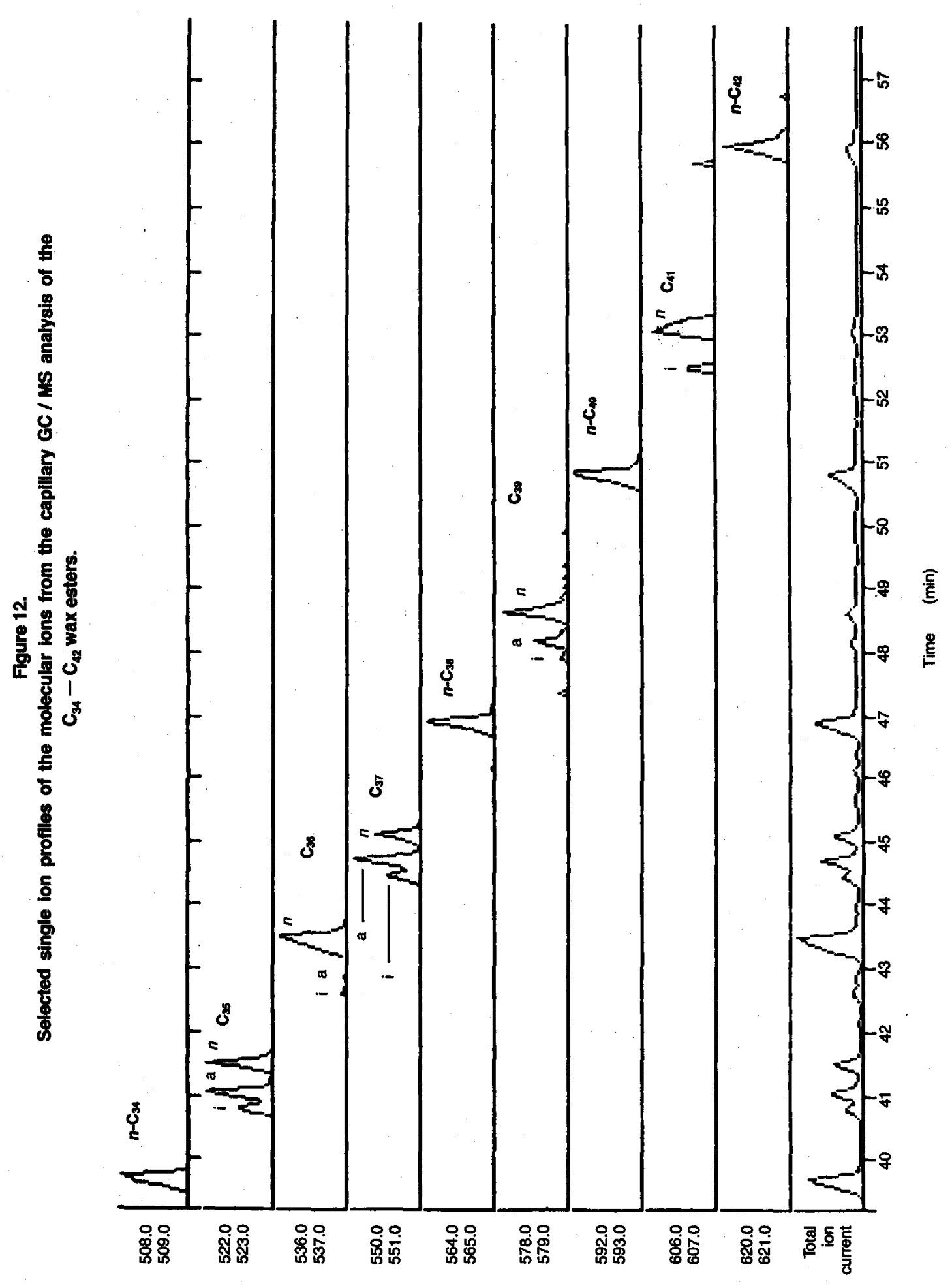




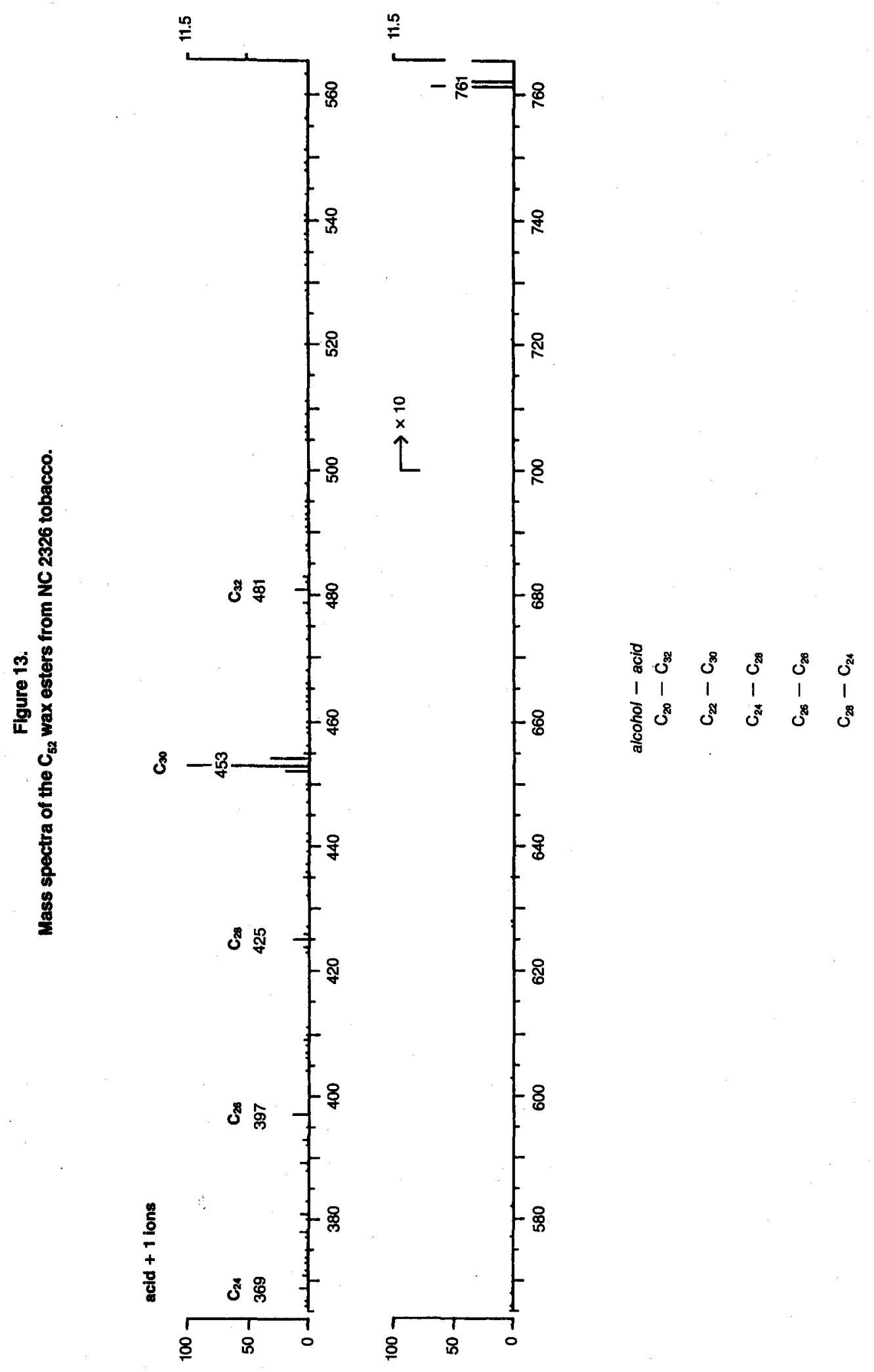


The mass spectrum of a typical straight-chain wax ester is shown in Fig. 9. Eicosyl tetradecanoate $\left(\mathrm{C}_{34}\right.$ wax ester) has a mass of 508 a.m.u. and is composed of a $C_{20}$ alcohol and $a \mathrm{C}_{14}$ acid. The base peak is the acid +1 ion at $m / z 229$, the acid -17 ion occurs at $m / z 211$, the alcohol +27 ion occurs at $m / z 325$, and the alcohol -18 ion is at $m / z 280$. Other ions of interest occur in the spectrum at $M-43(\mathrm{~m} / \mathrm{z} 465)$, acid $-43(\mathrm{~m} / \mathrm{z} 185)$ and acid $-57(\mathrm{~m} / \mathrm{z} 171)$ resulting from the losses of $\mathrm{C}_{3} \mathrm{H}_{7}$ and $\mathrm{C}_{4} \mathrm{H}_{9}$ fragments from the molecular ion and the acid moiety ion, respectively. Similarly, Fig. 10A shows that the mass spectra of the iso- $\mathrm{C}_{35}$ wax esters were composed primarily of the eicosyl isopentadecanoate isomer. The diagnostic ions occur in the spectra as follows: acid +1 at $m / z 243$, acid -17 at $m / z 225$, alcohol -18 at $\mathrm{m} / \mathrm{z} 280$, alcohol +27 at $\mathrm{m} / \mathrm{z} 325$, and the molecular ion at $\mathrm{m} / \mathrm{z} 522$. Note the presence of the $M-43$ ions from both the molecular ion at $m / z 479$ and from the acid moiety at $\mathrm{m} / \mathrm{z} 199$, corresponding to the loss of the $\mathrm{C}_{3} \mathrm{H}_{7}$ iso-branched group from the acid moiety. Fig. 10B shows the spectra of the anteiso- $\mathrm{C}_{35}$ wax esters, composed primarily of the eicosyl anteisopentadecanoate isomer. Comparison of Figures 10A and $10 \mathrm{~B}$ shows that the spectra are essentially identical, except for the ions resulting from the losses of the anteiso-branched group $\mathrm{C}_{4} \mathrm{H}_{9}+$ from the wax ester at $\mathrm{m} /$ $z 465(M-57)$ and from the acid moiety at $\mathrm{m} / \mathrm{z} 185$ (acid - 57) in the anteiso-branched isomer spectra (Fig. 10B). The mass spectrum of the normal straightchain $\mathrm{C}_{35}$ wax ester was similar to that of the $\mathrm{C}_{34}$ isomer (Fig. 9). All the diagnostic ions were present in the spectra of the major wax esters, but the weaker ions were sometimes missing in spectra of the less concentrated isomers. However, the most important diagnostic ions, which are the molecular ion and the acid +1 ion, were always present.

The capillary GC / MS total ion current chromatogram of the $\mathrm{C}_{30}-\mathrm{C}_{44}$ wax esters is given in Fig. 11. Note the designations for the iso-chain [i], anteiso-chain [a], and normal-chain [ $n]$ wax ester isomers and their elution order from the SE-54 capillary column. The elution order of iso-, anteiso-, and normal-chain esters is consistent with the elution order of aliphatic hydrocarbons with similar chain branching, also found in the cuticular waxes of tobacco leaf $(4,13)$. The data are more clearly depicted in selected single ion profiles of the molecular ions of the wax esters (Fig. 12). The data indicate the presence of extensively branched odd carbon number esters, compared to the relatively non-branched even carbon number isomers.

Identification of the individual wax esters was based upon the diagnostic ions discussed above, the fragmentation pattern resulting from branching of the acid moieties, and the elution order from the SE-54 capillary column of isomers within a carbon number series. The elution orders and MS fragmentation patterns of the normal straight-chain cuticular wax esters were identical with those of the synthetic wax ester standards discussed above. In most instances, a single capillary GC peak contained several isomers of wax esters re- sulting from various combinations of alcohol and acid moieties. As an example, Fig. 13 shows the mass spectra of the normal-chain $\mathrm{C}_{52}$ wax esters, which were shown to consist of five isomers, with the most abundant being the $\mathrm{C}_{22}$ alcohol $-\mathrm{C}_{30}$ acid ester.

A list of the wax ester isomers of NC 2326 tobacco leaf identified by cold on-column injection capillary GC/ MS is given in Table 2. The number of isomers generally increased with increased carbon number, as a result of an increase in possible alcohol-acid combinations in the $\mathrm{C}_{34}-\mathrm{C}_{40}$ carbon number wax ester range. For instance, the $\mathrm{C}_{34}$ wax esters consisted of only three isomers, with eicosyl tetradecanoate $\left(C_{20}\right.$ alcohol $-C_{14}$ acid) accounting for most of the weight of the $\mathrm{C}_{34}$ wax esters. On the other hand, there were 15 isomers of the $\mathrm{C}_{39}$ wax esters. The most abundant single wax ester isomer found in the isolate from NC 2326 was docosyl tetradecanoate, as one would have suspected; docosanol $\left(\mathrm{C}_{22}\right)$ and tetradecanoic acid $\left(\mathrm{C}_{14}\right)$ were the most abundant alcohol and acid found upon hydrolysis of the wax esters.

Table 2.

Wax esters Identifled from NC 2326 tobacco. *

\begin{tabular}{|c|c|c|}
\hline $\begin{array}{l}\text { Carbon } \\
\text { No. }\end{array}$ & $\begin{array}{c}\text { Alcohol - acid } \\
\text { moieties }\end{array}$ & Compound name \\
\hline $\mathrm{C}_{30}$ & $n-C_{18}-n-C_{14}$ & $n$-Hexadecyl $n$-tetradecanoate \\
\hline $\mathrm{C}_{31}$ & $\begin{array}{l}n-C_{17}-i-C_{14} \\
n-C_{16}-i-C_{15}\end{array}$ & $\begin{array}{l}\text { n-Heptadecyl i-tetradecanoate } \\
n \text {-Hexadecyl i-pentadecanoate }\end{array}$ \\
\hline & $\begin{array}{l}n-C_{17}-a-C_{14} \\
n-C_{18}-a-C_{15}\end{array}$ & $\begin{array}{l}n \text {-Heptadecyl a-tetradecanoate } \\
\text { n-Hexadecyl a-pentadecanoate }\end{array}$ \\
\hline . & $\begin{array}{l}n-C_{17}-n-C_{14} \\
n-C_{18}-n-C_{15}\end{array}$ & $\begin{array}{l}n \text {-Heptadecyl } n \text {-tetradecanoate } \\
n \text {-Hexadecyl } n \text {-pentadecanoate }\end{array}$ \\
\hline $\mathrm{C}_{32}$ & $n-C_{18}-i-C_{14}$ & n-Octadecyl i-tetradecanoate \\
\hline & $\begin{array}{l}n-C_{18}-n-C_{14} \\
n-C_{16}-n-C_{16} \\
n-C_{20}-n-C_{12}\end{array}$ & $\begin{array}{l}n \text {-Octadecyl } n \text {-tetradecanoate } \\
n \text {-Hexadecyl } n \text {-hexadecanoate } \\
n \text {-Eicosyl } n \text {-dodecanoate }\end{array}$ \\
\hline $\mathrm{C}_{33}$ & $\begin{array}{l}n-C_{20}-i-C_{13} \\
n-C_{10}-i-C_{14} \\
n-C_{18}-i-C_{15} \\
n-C_{17}-i-C_{16}\end{array}$ & $\begin{array}{l}n \text {-Eicosyl i-tridecanoate } \\
n \text {-Nonadecyl i-tetradecanoate } \\
\text { n-Octadecyl i-pentadecanoate } \\
\text { n-Heptadecyl i-hexadecanoate }\end{array}$ \\
\hline & $\begin{array}{l}n-C_{20}-a-C_{13} \\
n-C_{19}-a-C_{14} \\
n-C_{18}-a-C_{15} \\
n-C_{17}-a-C_{16}\end{array}$ & $\begin{array}{l}n \text {-Eicosyl a-tridecanoate } \\
\text { n-Nonadecyl a-tetradecanoate } \\
\text { n-Octadecyl a-pentadecanoate } \\
n \text {-Heptadecyl a-hexadecanoate }\end{array}$ \\
\hline & $\begin{array}{l}n-C_{19}-n-C_{14} \\
n-C_{18}-n-C_{15} \\
n-C_{20}-n-C_{13} \\
n-C_{17}-n-C_{18}\end{array}$ & $\begin{array}{l}n \text {-Nonadecyl n-tetradecanoate } \\
n \text {-Octadecyl n-pentadecanoate } \\
n \text {-Elcosyl } n \text {-tridecanoate } \\
n \text {-Heptadecyl } n \text {-hexadecanoate }\end{array}$ \\
\hline
\end{tabular}

*i: iso-branched,

a: anteiso-branched,

$n$ : normal straight chain. 
Table 2. Wax esters identified from NC 2326 tobacco. (cont'd.).

\begin{tabular}{|c|c|c|}
\hline $\begin{array}{l}\text { Carbon } \\
\text { No. }\end{array}$ & $\begin{array}{l}\text { Alcohol - acid } \\
\text { moieties }\end{array}$ & Compound name \\
\hline $\mathrm{C}_{34}$ & $\begin{array}{l}n-C_{20}-i-C_{14} \\
n-C_{18}-i-C_{16}\end{array}$ & $\begin{array}{l}\text { n-Eicosyl i-tetradecanoate } \\
\text { n-Octadecyl i-hexadecanoate }\end{array}$ \\
\hline : & $n-C_{20}-n-C_{14}$ & $n$-Eicosyl n-tetradecanoate \\
\hline $\mathrm{C}_{35}$ & $\begin{array}{l}n-C_{20}-i-C_{15} \\
n-C_{21}-i-C_{14}\end{array}$ & $\begin{array}{l}\text { n-Elcosyl i-pentadecanoate } \\
n \text {-Heneicosyl i-tetradecanoate }\end{array}$ \\
\hline & $\begin{array}{l}n-C_{20}-a-C_{15} \\
n-C_{21}-a-C_{14}\end{array}$ & $\begin{array}{l}n \text {-Eicosyl a-pentadecanoate } \\
n \text {-Heneicosyl a-tetradecanoate }\end{array}$ \\
\hline & $\begin{array}{l}n-C_{21}-n-C_{14} \\
n-C_{20}-n-C_{15}\end{array}$ & $\begin{array}{l}n \text {-Heneicosyl } n \text {-tetradecanoate } \\
n \text {-Eicosyl } n \text {-pentadecanoate }\end{array}$ \\
\hline $\mathrm{C}_{36}$ & $\begin{array}{l}n-C_{22}-i-C_{14} \\
n-C_{21}-i-C_{15} \\
n-C_{20}-i-C_{16}\end{array}$ & $\begin{array}{l}n \text {-Docosyl i-tetradecanoate } \\
n \text {-Heneicosyl i-pentadecanoate } \\
\text { n-Eicosyl i-hexadecanoate }\end{array}$ \\
\hline & $n-C_{21}-a-C_{15}$ & $n$-Heneicosyl a-pentadecanoate \\
\hline & $\begin{array}{l}n-C_{22}-n-C_{14} \\
n-C_{20}-n-C_{16}\end{array}$ & $\begin{array}{l}n \text {-Docosyl } n \text {-tetradecanoate } \\
n \text {-Eicosyl } n \text {-hexadecanoate }\end{array}$ \\
\hline $\mathrm{C}_{37}$ & $n-C_{22}-i-C_{15}$ & $n$-Docosyl i-pentadecanoate \\
\hline & $n-C_{22}-a-C_{15}$ & n-Docosyl a-pentadecanoate \\
\hline & $\begin{array}{l}n-C_{22}-n-C_{15} \\
n-C_{21}-n-C_{16} \\
n-C_{23}-n-C_{14} \\
n-C_{20}-n-C_{17}\end{array}$ & $\begin{array}{l}n \text {-Docosyl n-pentadecanoate } \\
n \text {-Heneicosyl } n \text {-hexadecanoate } \\
n \text {-Tricosyl } n \text {-tetradecanoate } \\
n \text {-Eicosyl } n \text {-heptadecanoate }\end{array}$ \\
\hline$C_{38}$ & $\begin{array}{l}n-C_{22}-i-C_{16} \\
n-C_{23}-i-C_{15}\end{array}$ & $\begin{array}{l}n \text {-Docosyl i-hexadecanoate } \\
n \text {-Tricosyl i-pentadecanoate }\end{array}$ \\
\hline & $\begin{array}{l}n-C_{21}-a-C_{17} \\
n-C_{23}-a-C_{15}\end{array}$ & $\begin{array}{l}n \text {-Heneicosyl a-heptadecanoate } \\
n \text {-Tricosyl a-pentadecanoate }\end{array}$ \\
\hline & $\begin{array}{l}n-C_{22}-n-C_{16} \\
n-C_{20}-n-C_{18} \\
n-C_{24}-n-C_{14}\end{array}$ & $\begin{array}{l}n \text {-Docosyl } n \text {-hexadecanoate } \\
n \text {-Eicosyl } n \text {-octadecanoate } \\
n \text {-Tetracosyl } n \text {-tetradecanoate }\end{array}$ \\
\hline $\mathrm{C}_{39}$ & $\begin{array}{l}n-C_{24}-i-C_{15} \\
n-C_{21}-i-C_{18} \\
n-C_{19}-i-C_{20} \\
n-C_{23}-i-C_{16} \\
n-C_{22}-i-C_{17}\end{array}$ & $\begin{array}{l}n \text {-Tetracosyl i-pentadecanoate } \\
n \text {-Heneicosyl i-octadecanoate } \\
n \text {-Nonadecyl i-eicosanoate } \\
n \text {-Tricosyl i-hexadecanoate } \\
n \text {-Docosyl i-heptadecanoate }\end{array}$ \\
\hline & $\begin{array}{l}n-C_{24}-a-C_{15} \\
n-C_{22}-a-C_{17} \\
n-C_{21}-a-C_{18} \\
n-C_{23}-a-C_{16}\end{array}$ & $\begin{array}{l}n \text {-Tetracosyl a-pentadecanoate } \\
n \text {-Docosyl a-heptadecanoate } \\
n \text {-Heneicosyl a-octadecanoate } \\
n \text {-Tricosyl a-hexadecanoate }\end{array}$ \\
\hline & $\begin{array}{l}n-C_{21}-n-C_{18} \\
n-C_{22}-n-C_{17} \\
n-C_{20}-n-C_{19} \\
n-C_{24}-n-C_{15} \\
n-C_{25}-n-C_{14} \\
n-C_{23}-n-C_{16}\end{array}$ & $\begin{array}{l}n \text {-Heneicosyl } n \text {-octadecanoate } \\
n \text {-Docosyl } n \text {-heptadecanoate } \\
n \text {-Eicosyl } n \text {-nonadecanoate } \\
n \text {-Tetracosyl } n \text {-pentadecanoate } \\
n \text {-Pentacosyl } n \text {-tetradecanoate } \\
n \text {-Tricosyl } n \text {-hexadecanoate }\end{array}$ \\
\hline
\end{tabular}

\begin{tabular}{|c|c|c|}
\hline $\begin{array}{l}\text { Carbon } \\
\text { No. }\end{array}$ & $\begin{array}{c}\text { Alcohol - acid } \\
\text { moieties }\end{array}$ & Compound name \\
\hline \multirow[t]{3}{*}{$\mathrm{C}_{40}$} & $\begin{array}{l}n-C_{22}-i-c_{18} \\
n-C_{24}-i-C_{16}\end{array}$ & $\begin{array}{l}n \text {-Docosyl i-octadecanoate } \\
n \text {-Tetracosyl i-hexadecanoate }\end{array}$ \\
\hline & $n-C_{25}-a-c_{15}$ & $n$-Pentacosyl a-pentadecanoate \\
\hline & $\begin{array}{l}n-C_{22}-n-C_{18} \\
n-C_{20}-n-C_{20} \\
n-C_{21}-n-C_{19} \\
n-C_{24}-n-C_{16} \\
n-C_{26}-n-C_{14}\end{array}$ & $\begin{array}{l}n \text {-Docosyl n-octadecanoate } \\
n \text {-Eicosyl n-eicosanoate } \\
n \text {-Heneicosyl n-nonadecanoate } \\
n \text {-Tetracosyl } n \text {-hexadecanoate } \\
n \text {-Hexacosyl } n \text {-tetradecanoate }\end{array}$ \\
\hline
\end{tabular}

$\mathrm{C}_{41} \quad n-\mathrm{C}_{28}-\mathrm{i}-\mathrm{C}_{15}$

$n-C_{23}-i-C_{18}$

$n-\mathrm{C}_{21}-\mathrm{i}-\mathrm{C}_{20}$

$n-\mathrm{C}_{23}-\mathrm{a}-\mathrm{C}_{18}$

$n-C_{22}-a-C_{19}$

$n-C_{21}-a-C_{20}$

$n-C_{25}-a-C_{18}$

$n-\mathrm{C}_{26}-\mathrm{a}-\mathrm{C}_{15}$

$n-C_{27}-a-C_{14}$

$n-C_{21}-n-C_{20}$

$n-C_{22}-n-C_{19}$

$n-C_{23}-n-C_{18}$

$n-C_{20}-n-C_{21}$

$\mathrm{C}_{42} \quad n-\mathrm{C}_{22}-n-\mathrm{C}_{20}$

$n-\mathrm{C}_{20}-n-\mathrm{C}_{22}$

$n-C_{24}-n-C_{18}$

$\mathrm{C}_{43} \quad n-\mathrm{C}_{26}-\mathrm{a}-\mathrm{C}_{17}$

$n-C_{23}-a-C_{20}$

$n-\mathrm{C}_{22}-\mathrm{a}-\mathrm{C}_{21}$

$n-C_{21}-a-C_{22}$

$n-\mathrm{C}_{20}-\mathrm{a}-\mathrm{C}_{23}$

$n-C_{19}-a-C_{24}$

$n-\mathrm{C}_{27}-n-\mathrm{C}_{18}$

$n-\mathrm{C}_{26}-n-\mathrm{C}_{17}$

$n-\mathrm{C}_{25}-n-\mathrm{C}_{18}$

$n-C_{24}-n-C_{19}$

$n-\mathrm{C}_{23}-n-\mathrm{C}_{20}$

$n-\mathrm{C}_{22}-n-\mathrm{C}_{21}$

$n-C_{21}-n-C_{22}$

$n$-Hexacosyl i-pentadecanoate

$n$-Tricosyl i-octadecanoate

n-Heneicosyl i-eicosanoate

$n$-Tricosyl a-octadecanoate

$n$-Docosyl a-nonadecanoate

$n$-Heneicosyl a-eicosanoate

$n$-Pentacosyl a-hexadecanoate

$n$-Hexacosyl a-pentadecanoate

$n$-Heptacosyl a-tetradecanoate

n-Heneicosyl n-eicosanoate

$n$-Docosyl $n$-nonadecanoate

$n$-Tricosyl $n$-octadecanoate

$n$-Eicosyl n-heneicosanoate

n-Docosyl n-eicosanoate

$n$-Eicosyl n-docosanoate

$n$-Tetracosyl n-octadecanoate

n-Hexacosyl a-heptadecanoate

$n$-Tricosyl a-eicosanoate

$n$-Docosyl a-heneicosanoate

$n$-Heneicosyl a-docosanoate

$n$-Eicosyl a-tricosanoate

n-Nonadecyl a-tetracosanoate

$n$-Heptacosyl $n$-hexadecanoate $n$-Hexacosyl $n$-heptadecanoate $n$-Pentacosyl $n$-octadecanoate $n$-Tetracosyl $n$-nonadecanoate $n$-Tricosyl n-eicosanoate n-Docosyl $n$-heneicosanoate $n$-Heneicosyl $n$-docosanoate

$\mathrm{C}_{44} \quad n-\mathrm{C}_{27}-\mathrm{a}-\mathrm{C}_{17}$

$n-C_{28}-a-C_{18}$

n-Heptacosyl a-heptadecanoate

$n-C_{24}-a-C_{20}$

$n-C_{22}-a-C_{22}$

$n-C_{21}-a-C_{23}$

$n-C_{20}-a-C_{24}$

$n-C_{28}-n-C_{16}$

$n-C_{28}-n-C_{18}$

$n-C_{24}-n-C_{20}$

$n-\mathrm{C}_{22}-n-\mathrm{C}_{22}$

$n-C_{20}-n-C_{24}$ $n$-Hexacosyl a-octadecanoate $n$-Tetracosyl a-eicosanoate $n$-Docosyl a-docosanoate $n$-Heneicosyl a-tricosanoate $n$-Eicosyl a-tetracosanoate

n-Octacosyl $n$-hexadecanoate $n$-Hexacosyl $n$-octadecanoate $n$-Tetracosyl $n$-eicosanoate $n$-Docosyl $n$-docosanoate $n$-Eicosyl $n$-tetracosanoate 


\begin{tabular}{|c|c|c|}
\hline $\begin{array}{l}\text { Carbon } \\
\text { No. }\end{array}$ & $\begin{array}{c}\text { Alcohol - acid } \\
\text { moleties }\end{array}$ & Compound name \\
\hline \multirow[t]{2}{*}{$\mathrm{C}_{45}$} & $\begin{array}{l}n-C_{21}-a-C_{24} \\
n-C_{28}-a-C_{17} \\
n-C_{28}-a-C_{19} \\
n-C_{22}-a-C_{23} \\
n-C_{20}-a-C_{25}\end{array}$ & $\begin{array}{l}n \text {-Heneicosyl a-tetracosanoate } \\
n \text {-Octacosyl a-heptadecanoate } \\
n \text {-Hexacosyl a-nonadecanoate } \\
n \text {-Docosyl a-tricosanoate } \\
n \text {-Eicosyl a-pentacosanoate }\end{array}$ \\
\hline & $\begin{array}{l}n-C_{27}-n-C_{18} \\
n-C_{25}-n-C_{20} \\
n-C_{23}-n-C_{22} \\
n-C_{22}-n-C_{23} \\
n-C_{21}-n-C_{24} \\
n-C_{20}-n-C_{25}\end{array}$ & $\begin{array}{l}n \text {-Heptacosyl n-octadecanoate } \\
n \text {-Pentacosyl } n \text {-eicosanoate } \\
n \text {-Tricosyl } n \text {-docosanoate } \\
n \text {-Docosyl } n \text {-tricosanoate } \\
n \text {-Heneicosyl } n \text {-tetracosanoate } \\
n \text {-Eicosyl } n \text {-pentacosanoate }\end{array}$ \\
\hline \multirow[t]{2}{*}{$C_{46}$} & $\begin{array}{l}n-C_{28}-a-C_{18} \\
n-C_{22}-a-C_{24}\end{array}$ & $\begin{array}{l}n \text {-Octacosyl a-octadecanoate } \\
n \text {-Docosyl a-tetracosanoate }\end{array}$ \\
\hline & $\begin{array}{l}n-C_{30}-n-C_{18} \\
n-C_{28}-n-C_{18} \\
n-C_{28}-n-C_{20} \\
n-C_{24}-n-C_{22} \\
n-C_{22}-n-C_{24} \\
n-C_{20}-n-C_{26} \\
n-C_{18}-n-C_{28}\end{array}$ & $\begin{array}{l}n \text {-Triacontyl n-hexadecanoate } \\
n \text {-Octacosyl } n \text {-octadecanoate } \\
\text { n-Hexacosyl } n \text {-eicosanoate } \\
n \text {-Tetracosyl } n \text {-docosanoate } \\
\text { n-Docosyl } n \text {-tetracosanoate } \\
\text { n-Elcosyl } n \text {-hexacosanoate } \\
\text { n-Octadecyl } n \text {-octacosanoate }\end{array}$ \\
\hline \multirow[t]{2}{*}{$\mathrm{C}_{47}$} & $\begin{array}{l}n-C_{22}-a-C_{25} \\
n-C_{21}-a-C_{26}\end{array}$ & $\begin{array}{l}n \text {-Docosyl a-pentacosanoate } \\
n \text {-Heneicosyl a-hexacosanoate }\end{array}$ \\
\hline & $\begin{array}{l}n-C_{29}-n-C_{18} \\
n-C_{27}-n-C_{20} \\
n-C_{24}-n-C_{23} \\
n-C_{22}-n-C_{25} \\
n-C_{21}-n-C_{28} \\
n-C_{20}-n-C_{27}\end{array}$ & $\begin{array}{l}n \text {-Nonacosyl n-octadecanoate } \\
n \text {-Heptacosyl } n \text {-eicosanoate } \\
n \text {-Tetracosyl } n \text {-tricosanoate } \\
n \text {-Docosyl } n \text {-pentacosanoate } \\
n \text {-Heneicosyl } n \text {-hexacosanoate } \\
n \text {-Eicosyl } n \text {-heptacosanoate }\end{array}$ \\
\hline \multirow[t]{2}{*}{$\mathrm{C}_{48}$} & $n-C_{21}-a-C_{27}$ & n-Heneicosyl a-heptacosanoate \\
\hline & $\begin{array}{l}n-C_{20}-n-C_{28} \\
n-C_{22}-n-C_{28} \\
n-C_{24}-n-C_{24} \\
n-C_{26}-n-C_{22} \\
n-C_{28}-n-C_{20} \\
n-C_{30}-n-C_{18} \\
n-C_{32}-n-C_{18}\end{array}$ & $\begin{array}{l}n \text {-Eicosyl n-octacosanoate } \\
n \text {-Docosyl } n \text {-hexacosanoate } \\
n \text {-Tetracosyl } n \text {-tetracosanoate } \\
n \text {-Hexacosyl } n \text {-docosanoate } \\
n \text {-Octacosyl } n \text {-eicosanoate } \\
n \text {-Triacontyl } n \text {-octadecanoate } \\
\text { n-Dotriacontyl } n \text {-hexadecanoate }\end{array}$ \\
\hline \multirow[t]{2}{*}{$\mathrm{C}_{49}$} & $\begin{array}{l}n-C_{22}-a-C_{27} \\
n-C_{21}-a-C_{28}\end{array}$ & $\begin{array}{l}\text { n-Docosyl a-heptacosanoate } \\
\text { n-Heneicosyl a-octacosanoate }\end{array}$ \\
\hline & $\begin{array}{l}n-C_{20}-n-C_{29} \\
n-C_{21}-n-C_{28} \\
n-C_{22}-n-C_{27} \\
n-C_{23}-n-C_{26} \\
n-C_{26}-n-C_{23} \\
n-C_{27}-n-C_{22} \\
n-C_{28}-n-C_{21}\end{array}$ & $\begin{array}{l}\text { n-Eicosyl } n \text {-nonacosanoate } \\
\text { n-Heneicosyl } n \text {-octacosanoate } \\
n \text {-Docosyl } n \text {-heptacosanoate } \\
n \text {-Tricosyl } n \text {-hexacosanoate } \\
n \text {-Hexacosyl } n \text {-tricosanoate } \\
n \text {-Heptacosyl n-docosanoate } \\
\text { n-Octacosyl } n \text {-heneicosanoate }\end{array}$ \\
\hline \multirow[t]{2}{*}{$C_{50}$} & $n-C_{22}-a-C_{28}$ & n-Docosyl a-octacosanoate \\
\hline & $\begin{array}{l}n-C_{20}-n-C_{30} \\
n-C_{22}-n-C_{28} \\
n-C_{26}-n-C_{24}\end{array}$ & $\begin{array}{l}n \text {-Eicosyl } n \text {-triacontanoate } \\
n \text {-Docosyl } n \text {-octacosanoate } \\
n \text {-Hexacosyl } n \text {-tetracosanoate }\end{array}$ \\
\hline
\end{tabular}

\begin{tabular}{|c|c|c|}
\hline $\begin{array}{l}\text { Carbon } \\
\text { No. }\end{array}$ & $\begin{array}{l}\text { Alcohol - acid } \\
\text { moieties }\end{array}$ & Compound name \\
\hline & $\begin{array}{l}n-C_{28}-n-C_{22} \\
n-C_{34}-n-C_{18}\end{array}$ & $\begin{array}{l}n \text {-Octacosyl } n \text {-docosanoate } \\
n \text {-Tetratriacontyl } n \text {-hexadecanoate }\end{array}$ \\
\hline \multirow[t]{2}{*}{$C_{51}$} & $n-C_{22}-a-C_{29}$ & n-Docosyl a-nonacosanoate \\
\hline & $n-C_{22}-n-C_{29}$ & n-Docosyl $n$-nonacosanoate \\
\hline$C_{52}$ & $\begin{array}{l}n-\mathrm{C}_{20}-n-\mathrm{C}_{32} \\
n-\mathrm{C}_{22}-n-\mathrm{C}_{30} \\
n-\mathrm{C}_{24}-n-\mathrm{C}_{28} \\
n-\mathrm{C}_{26}-n-\mathrm{C}_{26} \\
n-\mathrm{C}_{28}-n-\mathrm{C}_{24}\end{array}$ & $\begin{array}{l}\text { n-Eicosyl } n \text {-dotriacontanoate } \\
\text { n-Docosyl } n \text {-triacontanoate } \\
n \text {-Tetracosyl } n \text {-octacosanoate } \\
\text { n-Hexacosyl } n \text {-hexacosanoate } \\
n \text {-Octacosyl } n \text {-tetracosanoate }\end{array}$ \\
\hline
\end{tabular}

* i: iso-branched,

a: anteiso-branched,

$n$ : normal straight chain.

It should be emphasized that cold on-column injection capillary GC (7) was essential to the successful separation and identification of the wax esters. Conventional capillary GC injection procedures, such as the split and splitless techniques, require rapid volatilization of the sample prior to passing of the solute components onto the capillary column, and resulted in serious discrimination of these high molecular weight components in the injection port. In fact, concentration of isolates in preparation for split injection capillary GC of the higher mass wax esters would result in precipitation of the very components to be analyzed. On the other hand, cold on-column injection allowed $1-3 \mu \mathrm{l}$ of sample to be injected directly onto the capillary column without volatilization. This procedure assured the quantitative transfer of solute components onto the column. A dedicated capillary GC / MS interface was also critical in these analyses. The open-split interface design used in this work provided low dead volume, deactivated FS capillary tubing extending all the way to the MS source (11). Application of the above technique efficiently separated and delivered the wax esters to the MS source and resulted in successful analyses.

\section{REFERENCES}

1. Rowland, R. L., and P. H. Latimer: Flue-cured tobacco, IV. Isolation of solanesyl esters; Tob. Sci. 3 (1959) 1-3.

2. Rodgman, A., L. C. Cook and P. H. Latimer: The composition of cigarette smoke, II. Solanesyl and phytosteryl esters; Tob. Sci. 3 (1959) 125-128.

3. Rodgman, A., L. C. Cook, S. A. Bellin, S. S. Mims and G. W. Young: The composition of cigarette smoke, IX. An aliphatic ester fraction from tobacco and tobacco smoke; Tob. Sci. 6 (1962) $42-49$. 
4. Serverson, R. F., R. F. Arrendale, O. T. Chortyk, A. W. Johnson, D. M. Jackson, G. R. Gwynn, J. F. Chaplin and M. G. Stephenson: Quantitation of the major cuticular components from green leaf of different tobacco types; J. Agric. Food Chem. 32 (1984) $566-570$.

5. Severson, R. F., R. F. Arrendale, O. T. Chortyk, C. R. Green, F. A. Thome, J. L. Stewart and A. W. Johnson: Isolation and characterization of the sucrose esters of the cuticular waxes of green tobacco leaf; J. Agric. Food Chem. 33 (1985) 870-875.

6. Severson, R. F., A. W. Johnson and D. M. Jackson: Cuticular constituents of tobacco - Factors affecting their production and their role in insect and disease resistance and smoke quality; Recent Adv. Tob. Sci. 11 (1985) 105-174.

7. Arrendale, R. F., and O. T. Chortyk: Construction and application of a cold on-column injection system for capillary gas chromatography; J. High Resolut. Chromatogr. Chromatogr. Commun. 8 (1985) 62-68.

8. Arrendale, R. F., and R. M. Martin: Rapid method for preparing immobilized stationary phase apolar and medium polarity fused silica capillary columns; J. High Resolut. Chromatogr. Chromatogr. Commun., in press.

9. Stavely, J. R.: Disease resistance in Nicotiana Procedures for experimental use; U.S. Dep. Agric. Tech. Bull. 1586, 87, 1979.

10. Burk, L. G., G. V. Gooding, Jr., and J. F. Chaplin: Reaction of Nicotiana species and cultivars or breeding lines of Nicotiana tabacum to three strains of potato virus Y; Tob. Sci. 26 (1982) 85-88.
11. Arrendale, R. F., R, F. Severson and O. T. Chortyk: Open split interface for capillary gas chromatography/mass spectrometry; Anal. Chem. 56 (1984) 1533-1537.

12. Silverstein, R. M., and G. C. Bassler: Spectrometric identification of organic compounds, 2nd edition; John Wiley and Sons, Inc., New York, 1976, pp. 22-23.

13. Severson, R. F., K. L. McDuffie, R. F. Arrendale and $O$. T. Chortyk: A modified method for the rapid analysis of long-chain alkanes and neophytadiene from tobacco; Beitr. Tabakforsch. Int. 11 (1981) 27-32.

Authors' address:

Tobacco Quality and Safety Researcb Unit,

Richard B. Russell Agricultural Research Center,

Agricultural Research Service,

U.S. Department of Agriculture,

College Station Road,

P.O. Box 5677,

Athens, Georgia, 30613, U.S.A. 